\title{
Evaluasi Nilai Nutrisi dan Kecernaan In Vitro Beberapa Rumput Alam dari Lahan Perkebunan dan Padang Penggembalaan
}

\section{Evaluation of Nutritional Value and In Vitro Digestibility of Natural Grass on Plantation Land and Pasture}

\author{
M. Hambakodu* \\ Program Studi Peternakan, Fakultas Sains dan Teknologi, Universitas Kristen Wira Wacana, Sumba - \\ Indonesia \\ *Corresponding E-mail: marsel.hambakodu@unkriswina.ac.id \\ (Diterima: 31 Oktober 2020; Disetujui: 5 Februari 2021)
}

\begin{abstract}
ABSTRAK
Rumput alam di padang penggembalaan kecamatan Pandawai kabupaten Sumba Timur perlu didata nilai nutrisi dan kecernaannya karena memiliki jenis yang beragam dan merupakan pakan utama yang dikonsumsi oleh ternak ruminansia. Penelitian ini bertujuan untuk mengetahui nilai nutrisi dan kecernaan in vitro rumput alam dari lahan perkebunan dan padang penggembalaan. Evaluasi nilai nutrisi menggunakan uji proksimat dan kecernaan dilakukan secara in vitro menggunakan cairan rumen sapi Bali. Penelitian menggunakan metode survei, rumput dari lahan perkebunan adalah Cynodon dactylon (kandaung hondu karambo), Digitaria ciliaris (kandaung mbata kambaku), Cynodon dactylon (L) Pers. (kandaung hira panggu), Panicum maximum (ndaica), Echinochloa cruss-galli (uhu randu), sedangkan rumput dari padang penggembalaan adalah Heteropogon insignis (mbelar penji), Sorghum nitidum (moru kapuka), Brachiaria decumbes (wolu kamemu), Ischaemun timorense (kahanga keri), Brachiaria humidcola (bara minah). Hasil penelitian rumput alam dari lahan perkebunan memiliki nilai nutrisi dan kecernaan in vitro yang lebih tinggi dibandingkan rumput alam dari padang penggembalaan. Rumput alam Cynodon dactylon (L) Pers, Echinochloa cruss-galli, Cynodon dactylon, Panicum maximum, Digitaria ciliaris memiliki nilai nutrisi dan kecernaan bahan kering dan bahan organik yang unggul.
\end{abstract}

Kata kunci: kecernaan, rumput alam, perkebunan, pastura

\section{ABSTRACT}

Natural grass in the pastures of Pandawai sub-district, East Sumba district, needs to be recorded for its nutritional value and digestibility because it has various types and is the main feed consumed by ruminants. This study aims to determine the nutritional value and in vitro digestibility of natural grasses from plantation land and pasture land. Evaluation of nutritive value using proximate and digestibility tests was carried out in vitro using Bali cattle rumen fluid. Research using survey methods, grass from the plantation area is Cynodon dactylon (kandaung hondu karambo), Digitaria ciliaris (kandaung mbata kambaku), Cynodon dactylon (L) Pers. (kandaung hira panggu), Panicum maximum (ndaica), Echinochloa cruss-galli (uhu randu). In contrast, the grass from the pasture is Heteropogon insignis (mbelar penji), Sorghum nitidum (moru kapuka), Brachiaria decumbent (wolu kamemu), Ischaemun timorense (kahanga keri), Brachiaria humidicola (bara minah). The results of this study of natural grass from plantation land have higher nutritional value and in vitro digestibility than natural grass from pasture land. Natural grasses Cynodon dactylon (L) Pers, Echinochloa cruss-galli, Cynodon dactylon, Panicum maximum, Digitaria ciliaris have superior nutritional value and dry matter and organic matter digestibility.

Keywords: digestibility, natural grass, plantation land, pasture 


\section{PENDAHULUAN}

Usaha peternakan yang dipraktekkan oleh peternak di Pulau Sumba Provinsi Nusa Tenggara Timur adalah sistem pemeliharaan ekstensif atau semi ekstensif yang mengandalkan pastura alam dan areal perekebunan sebagai sumber pakan utama. Pastura alam dan areal perekebunan merupakan lahan sumber hijauan pakan bagi ternak ruminansia terutama oleh peternakan rakyat di daerah pedesaan (Yoku et al., 2015). Padang penggembalaan dan areal perkebunan hingga saat ini sangat diandalkan potensinya sebagai lumbung pakan bagi ternak (Koten et al., 2018).

Produktivitas ternak ruminansia yang dipelihara secara ekstensif maupun intensif sangat ditententukan oleh kondisi pakan baik secara kualitas, kunatitas dan kontinuitas. Produksi rumput alam pada musim hujan melimpah, dan pada musim hujan menurun. Potensi luas padang penggembalaan Sumba Timur seluas $221.371 \mathrm{Ha}$, sedangkan areal perkebunan 30.480 Ha (Badan Pusat Statistik, 2019). Rumput alam di pastura alam dan lahan perkebunan sangat beragam jenisnya dan perlu identifikasi dan potensi nutrien serta kecernaannya dalam rumen ternak ruminansia.

Permasalahan pengembangan ternak ruminansia adalah kualitas pakan yang buruk sehingga terjadi defesiensi nutrien yang dapat menyebabkan ternak mengalami penurunan bobot badan, kurus, tidak sehat, lumpuh kaki, gagal bunting, kematian induk dan anak. Kekurangan nutrien pakan akan mempengaruhi performans ternak, hal ini karena gambaran nutrien pakan akan menentukan kecernaan dalam rumen sehingga memberikan dampak pada pertumbuhan ternak. Menurut (Hambakodu et al., 2019) komposisi nutrien bahan pakan yang berbedabeda dicerminkan melalui produk metabolisme rumen dan kecernaan yang mempengaruhi performans ternak. Kecernaan pakan dalam rumen dipengaruhi oleh kandungan lignin pakan, lignin yang ada dalam pakan menghambat kerja mikroorganisme rumen dalam mencerna pakan. Kandungan lignin yang rendah dalam pakan maka miroba rumen dengan mudah mencerna pakan hijauan tropis (Hambakodu et al., 2020). Kandungan nutrien rumput alam serta kecernaan nutrien masingmasing rumput alam yang tumbuh di lahan perkebunan dan padang penggembalaan perlu dievaluasi karena datanya masih terbatas. Berdasarkan permasalahan tersebut, maka perlu adanya kajian nilai nutrisi dan kecernaan nutrien secara in vitro rumput alam di lahan perkebunan dan padang penggembalaan Kecamatan Pandawai Sumba Timur.

\section{METODE}

\section{Tempat Penelitian}

Penelitian ini dilaksanakan di areal perkebunan dan padang penggembalaan kecamatan Pandawai kabupaten Sumba Timur untuk pengambilan sampel rumput. Uji nilai nutrisi (proksimat) dilakukan di Laboratorium Ilmu Nutrisi dan Pakan, Universitas Diponegoro. Uji in vitro kecernaan bahan kering dan bahan organik dilakukan di Laboratorium Kimia Pakan Fakultas Peternakan Universitas Nusa Cendana Kupang.

\section{Materi Penelitian}

Rumput alam yang digunakan dalam penelitian adalah rumput alam dari lahan perkebunan yakni Cynodon dactylon(L) Pers, Echinochloa cruss-galli, Cynodon dactylon, Panicum maximum, Digitaria ciliaris, sedangkan rumput alam dari padang penggembalaan yakni Heteropogon insignis, Sorghum nitidum, Brachiaria decumbes, Ischaemun timorense, Brachiaria humidcola.

Bahan yang digunakan adalah bahan untuk analisis proksimat, cairan rumen dari sapi Bali, larutan McDougall, larutan pepsin $\mathrm{HCl} 0,2 \%$, aquades, $\mathrm{Na}_{2} \mathrm{SO}_{3}$, dan alkohol, sedangkan alat yang digunakan yaitu timbangan digital, disk mill ukuran $2 \mathrm{~mm}$, timbangan analitik merk Ohaus, kertas saring, krusibel, waterbath, sentrifuse, thermometer, termos, kain kasa, tabung fermentor, tabung 
reaksi, eksikator, oven, dan tanur.

\section{Pelaksanaan Penelitian}

Rumput alam diambil langsung dari lahan perkebunan dan padang penggembalaan Kecamatan Pandawai Kabupaten Sumba Timur. Rumput alam dijemur dibawa sinar matahari selama 2 hari dan digiling menggunakan disk mill ukuran $2 \mathrm{~mm}$. Analisis proksimat menggunakan metode (AOAC, 1990). Pelaksanaan in vitro dengan metode Tilley and Terry (1963). Sampel ditimbang sebesar $\pm 0,5 \mathrm{~g}$, lalu dimasukan ke dalam tabung fermentor dan dicampur dengan larutan McDougall sebanyak $40 \mathrm{ml}$ sebagai larutan penyangga pengganti saliva dan cairan rumen sapi Bali sebanyak $10 \mathrm{ml}$ yang diperoleh dari rumah potong hewan Kota Kupang yang sebelumnya sapi Bali tersebut diberi pakan berbasis rumput alam. Kemudian diinkubasi ke dalam Waterbath pada suhu $\pm 39^{\circ} \mathrm{C}$ selama $2 \mathrm{x} 48$ jam. Pemberhentian proses fermentasi dilakukan dengan cara meneteskan 2 tetes larutan $\mathrm{HgCl}_{2}$ jenuh. Perhitungan kecernaan selama $2 \times 48$ jam. Setelah masa inkubasi $2 \times 48$ jam, residu disaring dengan krusibel Gooch, kemudian dianalisis kandungan kecernaan BK dan BO.

\section{Peubah yang Diamati}

Peubah yang diamati adalah nilai nutrisi, kecernaan bahan kering (KCBK) dan kecernaan bahan organik (KCBO). Rumus untuk perhitungan kecernaan menurut Tilley \& Terry (1963) sebagai berikut:

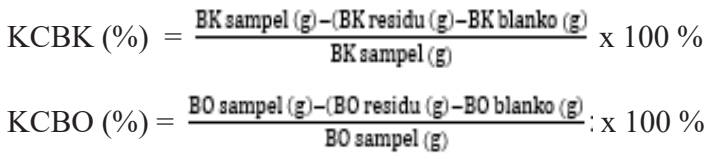

\section{Rancangan Penelitian}

Penelitian ini menggunakan metode survei. Sebanyak 10 jenis rumput, rumput dari lahan perkebunan adalah Cynodon dactylon (kandaung hondu karambo), Digitaria ciliaris (kandaung mbata kambaku), Cynodon dactylon (L) Pers. (kandaung hira panggu), Panicum maximum (ndaica), Echinochloa cruss-galli (uhu randu), sedangkan rumput dari padang penggembalaan adalah Heteropogon insignis (mbelar penji), Sorghum nitidum (moru kapuka), Brachiaria decumbes (wolu kamemu), Ischaemun timorense (kahanga keri), Brachiaria humidcola (bara minah). Data dianalisis menggunakan metode deskriptif dengan menggunakan standar deviasi dan rataan.

\section{HASIL DAN PEMBAHASAN}

\section{Gambaran Nutrien Beberapa Jenis Rumput Alam dari Lahan Perkebunan dan Padang Penggembalaan}

Kandungan nutrien masing-masing rumput alam di areal perkebunan dan padang penggembalaan dilihat pada Tabel 1, rumput alam yang berasal dari lahan perkebunan yakni Cynodon dactylon (kandaung hondu karambo), Digitaria ciliaris (kandaung mbata kambaku), Cynodon dactylon (L) Pers. (kandaung hira panggu), Panicum maximum (ndaica), Echinochloa cruss-galli (uhu randu). Rumput alam yang berasal dari padang penggembalaan yakni Heteropogon insignis (mbelar penji), Sorghum nitidum (moru kapuka), Brachiaria decumbes (wolu kamemu), Ischaemun timorense (kahanga keri), Brachiaria humidcola (bara minah). Potensi kandungan nutrien rumput alam yang berasal dari lahan perkebunan lebih baik daripada rumput alam yang berasal dari padang penggembalaan. Keunggulan nutrien bahan organik, protein kasar, lemak kasar rumput alam dari areal perkebunan didukung oleh faktor unsur hara tanah maupun bahan organik serta kelembaban yang lebih baik dibanding di padang penggembalaan. Kandungan nutrien rumput alam digambarkan nilai TDN yang dihasilkan, rumput alam di areal perkebunan memiliki nilai TDN yang lebih tinggi, selain itu juga didukung oleh kandungan serat kasar yang lebih rendah dibanding rumput alam dari padang penggembalaan. Nilai TDN yang digunakan merupakan pendugaan TDN menurut Wardeh (1981), pendugaan TDN ini dianggap lebih akurat (Hernaman et al., 2019). Kandungan protein kasar rumput alam di Pulau Sumba berkiasar antara $3-12 \%$, 
Tabel 1. Kandungan Nutrien Rumput Alam dari lahan perkebunan dan padang penggembalaan

\begin{tabular}{|c|c|c|c|c|c|c|c|c|}
\hline Jenis Rumput & $\mathrm{BK}$ & $\mathrm{BO}$ & PK & LK & SK & BETN & $\mathrm{KH}$ & TDN \\
\hline \multicolumn{9}{|l|}{ Perkebunan } \\
\hline $\begin{array}{l}\text { Cynodon dactylon } \\
\text { (kandaung hondu karambo) }\end{array}$ & 84,01 & 83,12 & 10,38 & 0,16 & 41,86 & 30,72 & 72,58 & 42,14 \\
\hline $\begin{array}{l}\text { Digitaria ciliaris (kandaung } \\
\text { mbata kambaku) }\end{array}$ & 88,45 & 85,05 & 11,97 & 1,24 & 59,56 & 12,28 & 71,84 & 47,92 \\
\hline $\begin{array}{l}\text { Cynodon dactylon (L) Pers. } \\
\text { (kandaung hira panggu) }\end{array}$ & 87,05 & 87,11 & 9,08 & 1,64 & 48,17 & 28,22 & 76,39 & 45,94 \\
\hline Panicum maximum (ndaica) & 83,42 & 88,00 & 9,14 & 0,54 & 44,29 & 34,03 & 78,32 & 41,27 \\
\hline $\begin{array}{l}\text { Echinochloa cruss-galli } \\
\text { (uhu randu) }\end{array}$ & 86,45 & 75,05 & 12,70 & 0,29 & 36,76 & 25,30 & 62,06 & 47,55 \\
\hline \multicolumn{9}{|l|}{ Padang Penggembalaan } \\
\hline $\begin{array}{l}\text { Heteropogon insignis } \\
\text { (mbelar penji) }\end{array}$ & 89,75 & 91,63 & 4,03 & 3,04 & 41,70 & 42,86 & 84,56 & 48,87 \\
\hline $\begin{array}{l}\text { Sorghum nitidum (moru } \\
\text { kapuka) }\end{array}$ & 87,32 & 88,24 & 4,43 & 2,03 & 50,20 & 31,58 & 81,78 & 43,84 \\
\hline $\begin{array}{l}\text { Brachiaria decumbes (wolu } \\
\text { kamemu) }\end{array}$ & 89,92 & 85,89 & 3,21 & 2,25 & 47,39 & 33,04 & 80,43 & 36,28 \\
\hline $\begin{array}{l}\text { Ischaemun timorense } \\
\text { (kahanga keri) }\end{array}$ & 88,96 & 89,39 & 4,59 & 2,78 & 39,63 & 42,39 & 82,02 & 44,96 \\
\hline $\begin{array}{l}\text { Brachiaria humidcola (bara } \\
\text { minah) }\end{array}$ & 89,28 & 76,63 & 3,37 & 1,66 & 42,02 & 29,58 & 71,60 & 42,61 \\
\hline
\end{tabular}

Keterangan: TDN berdasarkan rumus Wardeh (1981) : TDN $=-14,8356+1,3310(\% \mathrm{PK})+0,7923(\%$ $\mathrm{BETN})+0,9787(\% \mathrm{LK})+0,5133(\% \mathrm{SK}) ; \mathrm{TDN}=$ total digestible nutrient, $\mathrm{KA}=$ kadar air, $\mathrm{BK}=$ bahan kering, $\mathrm{BO}=$ bahan organik, $\mathrm{PK}=$ protein $\mathrm{kasar}, \mathrm{LK}=$ lemak kasar, $\mathrm{SK}=$ serat kasar, $\mathrm{BETN}=$ bahan ekstrak tanpa nitrogen, $\mathrm{KH}=$ karbohidrat.

sedangkan kandungan serat kasar berkisar antara $36,76-59,56 \%$.

\section{Kecernaan Bahan Kering Beberapa Rumput Alam dari Lahan Perkebunan dan Padang Penggembalaan Kecamatan Pandawai Kabupaten Sumba Timur}

Kecernaan bahan kering memberikan gambaran proporsi bahan organik yang dicerna oleh enzim pencernaan yang dihasilkan mikroba rumen. Analisis ragam menunjukkan kecernaan bahan organic berbeda nyata $(\mathrm{p}<0,05)$ pada setiap jenis rumput alam (Tabel 2). Kecernaan bahan kering rumput Cynodon dactylon(L) Pers. (kandaung hira panggu) tertinggi $(54,32 \%)$, kemudian diikuti rumput lainnya Echinochloa cruss-galli (uhu randu) 48,57\%; Cynodon dactylon (kandaung hondu karambo) 47,18\%; Panicum maximum (ndaica) 42,98\%, Digitaria ciliaris (kandaung mbata kambaku) 42,54\% dibandingkan rumput alam yang tumbuh di areal padang penggembalaan. Tingginya kecernaan bahan kering pada rumput ini didukung dengan kandungan bahan kering yang tinggi pula, dan rumput ini merupakan rumput alam yang tumbuh pada areal perkebunan. Rumput alam pada areal perkebunan memperoleh unsur hara tanah yang lebih baik dibandingkan di padang penggembalaan. Komposisi kimia dan degradasi rumput alam dalam rumen ternak memberikan efek yang berbeda-beda secara in vitro (Keim et al., 2018). Faktor lain ketersediaan rumput dipengaruhi oleh lokasi, cuaca, musim, kualitas tanah (Nurlaha et al., 
Tabel 2. Kecernaan Bahan Kering dan Bahan Organik Beberapa Rumput Alam dari Lahan Perkebunan dan Padang Penggembalaan Kecamatan Pandawai Kabupaten Sumba Timur

\begin{tabular}{lll}
\hline Jenis rumput & KCBK (\%) & KCBO (\%) \\
\hline Perkebunan & & \\
\hline Cynodon dactylon (kandaung hondu karambo) & $47,18 \pm 0,20$ & $43,13 \pm 0,02$ \\
Digitaria ciliaris (kandaung mbata kambaku) & $42,54 \pm 0,10$ & $39,36 \pm 0,00$ \\
Cynodon dactylon (L) Pers. (kandaung hira panggu) & $54,32 \pm 0,02$ & $52,22 \pm 0,03$ \\
Panicum maximum (ndaica) & $42,98 \pm 0,00$ & $41,31 \pm 0,10$ \\
Echinochloa cruss-galli (uhu randu) & $48,57 \pm 0,00$ & $45,00 \pm 0,01$ \\
\hline Padang Penggembalaan & & \\
\hline Heteropogon insignis (mbelar penji) & $30,82 \pm 0,04$ & $28,92 \pm 0,00$ \\
Sorghum nitidum (moru kapuka) & $35,91 \pm 0,00$ & $33,86 \pm 0,00$ \\
Bracharia decumbes (wolu kamemu) & $35,32 \pm 0,05$ & $32,08 \pm 0,00$ \\
Ischaemum timorense (kahanga keri) & $35,87 \pm 0,00$ & $31,89 \pm 0,02$ \\
Brachiaria humidcola (bara minah) & $33,47 \pm 0,00$ & $31,12 \pm 0,00$ \\
\hline
\end{tabular}

2014).

\section{Kecernaan Bahan Organik Beberapa Rumput Alam dari Lahan Perkebunan dan Padang Penggembalaan Kecamatan Pandawai Kabupaten Sumba Timur}

Kecernaan bahan organik memberikan gambaran proporsi bahan organik (karbohidrat, protein dan lemak) yang dicerna oleh enzim pencernaan mikroba rumen. Analisis ragam menunjukkan kecernaan bahan organic berbeda nyata $(\mathrm{p}<0,05)$ pada setiap jenis rumput alam. Kecernaan bahan organic rumput alam. Kecernaan bahan kering rumput Cynodon dactylon(L) Pers. (kandaung hira panggu) tertinggi (54,32\%), Echinochloa cruss-galli (uhu randu) 45,00\%; Cynodon dactylon (kandaung hondu karambo) 43,15\%; Panicum maximum (ndaica) 41,31\%, Digitaria ciliaris (kandaung mbata kambaku) $39,36 \%$ dibandingkan rumput alam pada areal padang penggembalaan. Tingginya kecernaan bahan organik pada rumput ini didukung oleh tingginya kecernaan bahan kering dan kandungan bahan organik rumput. Kecernaan bahan organik dari suatu pakan juga disebabkan oleh kandungan serat kasar dan protein kasar pakan (Tulung et al., 2020). Kandungan protein kasar dan serat kasar dari rumput alam berbeda-beda sehingga menyebabkan nilai kecernaan berbeda. Kecernaan bahan organik dan bahan kering pada rumput alam di padang penggembalaan kecamatan Pandawai lebih rendah dibandingkan hasil penelitian (Ati et al., 2018) yang melaporkan bahwa kecernaan bahan kering dan bahan organik hijauan padang penggembalaan di Kupang Barat sebesar 45,72\% dan 47,60\%. Hal ini disebabkan kondisi tanah dan lingkungan yang berbeda sehingga unsur hara tanah yang dihasilkan dan nutrien hijauan juga berbeda.

\section{KESIMPULAN}

Nilai nutrisi, kecernaan bahan kering (KCBK) dan kecernaan bahan organik (KCBO) rumput alam dari areal perkebunan lebih tinggi daripada rumput alam dari padang penggembalaan. Rumput Cynodon dactylon(L) Pers. (kandaung hira panggu) memiliki nilai nutrisi, kecernaan bahan kering dan bahan organik tertinggi yakni 54,32\% dan $52,22 \%$.

\section{UCAPAN TERIMA KASIH}

Penulis menyampaikan terima kasih kepada Universitas Kristen Wira Wacana 
Sumba yang telah membiayai penelitian ini melalui Program Kerja Program Studi Peternakan melalui Penelitian Dosen Mandiri (PDM) Tahun Akademik 2021.

\section{DAFTAR PUSTAKA}

AOAC. 1990. Association of Official Analytical Chemists. 15th edition. Association of Official Analytical Chemists, Arlington, Virginia, USA.

Ati, A. R. A., Manggol, Y. H. dan Osa, D. B. 2018. Kecernaan Bahan Kering Dan Bahan Organik Secara In Vitro Hijauan Padang Penggembalaan Batu Beringin Desa Sumlili Kecamatan Kupang Barat , Kabupaten Kupang. Jurnal Nukleus Peternakan, 5(2): 155-162.

Badan Pusat Statistik. 2019. Provinsi Nusa Tenggara Timur Dalam Angka 2019. In Badan Pusat Statistik Provinsi Nusa Tenggara Timur, pp. 1-657.

Hambakodu, M., Kaka, A., dan Ina, Y. T. 2020. Kajian In Vitro Kecernaan Fraksi Serat Hijauan Tropis pada Media Cairan Rumen Kambing. Jurnal Ilmu Dan Teknologi Peternakan Tropis, 7(1): 29.

Hambakodu, M., Pangestu, E. dan Achmadi, J. 2019. Substitusi rumput gajah dengan rumput laut coklat (Sargassum polycystum) terhadap produk metabolisme rumen dan kecernaan nutrien secara in vitro. Jurnal Ilmu-Ilmu Peternakan, 29(1): 37-45.

Hernaman, I., Ainunisa, N., Hidayat, R., Tarmidi, A. R., Dhalika, T., Budiman, A., dan Rahmat, D. 2019. Perbandingan Model Pendugaan Total Digestible Nutrients (TDN) dan Protein Tercerna pada Domba Garut Jantan yang Diberi Ransum Berbasis Bahan Pakan Lokal.
Jurnal Agripet, 19(1): 1-6.

Keim, J. P., Cabanilla, J., Balocchi, O., and Pulido, R. G. 2018. In vitro fermentation and in situ rumen degradation kinetics of summer forage brassica plants In vitro fermentation and in situ rumen degradation kinetics of summer forage brassica plants. Animal Production Science, August.

Koten, B. B., Naisoko, R., Wea, R., Semang, A., Lapenanga, T. 2018. Produksi Bahan Organik, Protein Kasar Danbahan Ekstrak Tanpa Nitrogen Hijauan Pastura Alam Yang Diintroduksi Jenis Rumput Dan Legum Yang Berbeda. Partner, 23(2): 773-781.

Nurlaha, Setiana, A. dan Asminaya, N. S. 2014. Identifikasi Jenis Hijauan Makanan Ternak di Lahan Persawahan Desa Babakan Kecamatan Dramaga Kabupaten Bogor. Jurnal Ilmu Dan Teknologi Peternakan Tropis, 1(1): 54-62.

Tulung, Y.L.R. dan A. F. Pendong., B. T. 2020. Evaluasi Nilai Biologis Pakan Lengkap Berbasis Tebon Jagung dan Rumput Campuran Terhadap Kinerja Produksi Sapi Peranakan Ongole (PO). Zootec, 40(1): 2612-8698.

Tilley, J. M. A. and R. A. Terry. 1963. A Two Stage Technique for the In Vitro. Digestion of Crops. British Grassl J. British Grassland Society, 18: 104-111.

Yoku., Onesimus., Supriyantono., A; Widayati., T., dan Sumpe, I. 2015. Komposisi Botani dan Persebaran Jenis-Jenis Hijauan Lokal Padang Pengembalaan Alam di Papua Barat. Pastura: Journal of Tropical Forage Science, 4(2): 62-65. 